\title{
DAKWAH COMMUNICATION STRATEGY IN EMPOWERING THE LABOR COMMUNITY IN PANJANG DISTRICT BANDAR LAMPUNG CITY TO IMPROVE THEIR RELIGIOUS PRACTICE
}

\author{
Aliyandi A. Lumbu \\ Institut Agama Islam Negeri Metro \\ Iringmulyo, Metro, Lampung, Indonesia, 34112 \\ Email: aliyandi@gmail.com

\begin{tabular}{c|c|c}
\hline Received: & Revised: & Approved: \\
$20 / 09 / 2020$ & $16 / 11 / 2020$ & $14 / 12 / 2020$ \\
\hline
\end{tabular}

DOI: http:/ / dx.doi.org/10.32332/akademika.v25i2.2399

\begin{abstract}
(@) (1) (-)
Dakwah Communication Strategy In Empowering The Labor Community In Panjang District Bandar Lampung City To Improve Their Religious Practice Licensed Under a Creative Commons Attribution-ShareAlike 4.0 International License
\end{abstract}

\begin{abstract}
This research is to explain about the role of Dakwah communication strategy in the empowerment of the labor community in Panjang Sub-District, Bandar Lampung in improving the practice of the implementation of sharia. This is descriptive qualitative research, where the data were collected throuh interviews, observation, and documentation. The data were then analyzed qualitatively using inductive thinking approach. The result of this research shows that the communication strategy used by the preacher in Panjang Sub-district was by giving motivation through the message of dawah conveyed to the community, Providing religious guidance, including religious activities such as five-time prayer, memorizing prayers, taking care of the corps and protecting the environment, establishing good relations with the community, either through regular recitation at the ta'lim assembly or taking the advantage of Arisan for savings and loan activities, interacting and seeing firsthand situation and conditions that exist in the community, then cooperate with the government by providing assistance in the form of funds and food. The most inhibiting factor is mad'u, especially in terms of understanding the message (somatic), closed to change (self-image), and motivation, marked by the passiveness communicant in receiving da'wah from the preacher because the preacher can not fully know the limits of somatic knowledge from the community.
\end{abstract}

Keywords: Dakwah, Communiction Strategy, Labor Community, Empowerment, Religious Practice

\section{A. Introduction}

Dakwah is a development movement carried out to enforce Amar ma'ruf and nahi Munkar so that the benefit of humanity realizes in this world and hereafter. As a development movement, Dakwah is present in the form of effective communication between a human being as a messenger and another human being as the recipient of the message of Dakwah. Besides, communication in Dakwah is also intertwined in the relationship of man with his creator because the success of Dakwah is also the role of God as a giver of guidance to the right. Thus, Dakwah is a communication process that determines the development movement towards social change.

Judging from one of the educational curricula about the provision of da'wah offered by the two largest Islamic organizations in Indonesia, namely the material of Al-Islam and Muhammadiyah (AIK) which is taught at Muhammadiyah, and the Islamic Education of the 
Archipelago (Aswaja) taught by Nahdlatul Ulama is more moderate than the material of preaching is in the Middle East. In the midst of transnational Islamic movements and global salafism, these new forms have proven to have contributed to ensuring the security and stability of the Unitary State of the Republic of Indonesia (NKRI). ${ }^{1}$ Besides, other da'wah strategies are those carried out from among Habib (Descendants of the Prophet Muhammad SAW). Among them is Habib Syech bin Abdul Qodir Assegaf's da'wah strategy, which uses public speaking skills, Habib Syaich also uses the media of performing the Salawat recitation to attract the object of da'wah - and widely accepted by most people in Indonesia. ${ }^{2}$

As a movement that adheres to the principle of illahiyyah value in the form of enjoining right and forbidding the wrong, Dakwah is seen as an Islamic movement that includes not only the practice of theory but also the practice. Thus, Dakwah contains a very deep meaning, it is not only about one side of human life but also covers various dimensions of human life in the aspects of information, communication, education, economics, socio-cultural, and various other aspects. Seeing the diversity of the dimensions of human life as the object of Dakwah, it can be said that Dakwah is not only the obligation of a mubaligh, scholars, Kiai, or Dakwah activists only, but it becomes the obligation of all human individuals themselves.

The strategy is very important in human activities in organizations, institutions, mosques, schools, factories, as well as household activities and personal activities of a person in daily life because the strategy is line of struggle that concerns the determination of the basic purpose, personal place or terrain, way, time and equipment in achieving the final goal. ${ }^{3}$

The strategy is inseparable from the word tactic that creates a connection as a way to direct energy, funds, and human resources to influence Muslims in various positive ways to unite the Islamic community. While the strategy of Dakwah has been carried out since the time of the messenger of Allaah. However, at that time the process of Dakwah has not been discussed individually scientifically and still joined by the psychology of dakwah; lately, it feels extraordinary efforts to review and observe the strategy of dawah communication, due to the emergence of an urgent competition from both Christian mission groups in Indonesia and such rapid social change and the level of knowledge position on Dakwah strategy which have become independent sciences.

Religion as a system of practical life realities has flexibility, appreciation, and accommodation for developing traditions and cultures. Social integration is a social process of a particular member of society; they are aware of building solidarity based on strong relationships in building the nation. The social integration process can run well if it is supported by good social norms and customs. ${ }^{4}$ Renewing the da'wah formula in the era of global information and communication technology is a must in the context of the times' demands. It is necessary to study new da'wah strategies that can touch both personal and social aspects. So that it can lead to positive interactions between da'wah actors and the surrounding community. Thus da'wah will be able to achieve the desired goal, namely to realize what is needed by humans in everyday life. ${ }^{5}$

The religion of Islam was revealed in an advance to be a guide for every aspect of humn

1 Suyadi Suyadi, "Mainstreaming The Knowledge Of Islamic Education With Progress And Of Islam Nusantara Education," AKADEMIKA: Jurnal Pemikiran Islam 24, no. 1 (2019): 39-66, https://doi.org/10.32332/akademika.v24i1.1613.

2 Arif Zamhari dan Imam Mustofa, “The Popular Da'wah Movement In Urban Communities: The Role Of Hadrami Scholars' Da'wah In Response To Religious Radicalism In Indonesia," AKADEMIKA: Jurnal Pemikiran Islam 25, no. 1 (2020): 185-208, https:/ / doi.org/10.32332/akademika.v25i1.2385.

3 Bintoro Tjokro Mijoyo dan Mustafat Jaya, Teori Dan Strategi Pembangunan Nasional (Jakarta: Gunung Agung, 2015), 14.

4 Widhiya Ninsiana, "Islam Dan Integrasi Sosial Dalam Cerminan Masyarakat Nusantara," AKADEMIKA: Jurnal Pemikiran Islam 21, no. 2 (2016): 357, https://ejournal.metrouniv.ac.id/index.php/akademika/article/view/472.

5 M. Nasor, "Dakwah Sebagai Instrumen Penanggulangan Radikalisme Di Era Digital," AKADEMIKA: Jurnal Pemikiran Islam 22, no. 1 (2017): 27-50, https:/ / doi.org/10.32332/akademika.v22i1.613. 
beings, not only regulating rituals, but Islam coming firmly to elevate degrees with the very rapid development and technology of information. In the rush of advancement of Science which was manifested through conveniences and pleasures offered by technological advance have encouraged the role and function of dawah to be able to compete with these technological stimuli. This is based on the thought that we have not been able to fully enjoy an adagium stating that the technology is neutral. The technological environment cannot be said to be neutral; on the contrary, it takes part in shaping human behavior itself, as well as other environments, both physical and non-physical environment (Ideology), and so on. ${ }^{6}$

Technological change will also continue to be followed by mental changes and then produce social change with all consequences. Social change is as a result of technological development and Science also offers its norms that may be contrary with the ideal norms that exist in individual human beings. ${ }^{7}$

One of the impacts on the time of globalization is now many people with the onion of poverty in the sense of low economy, poor wealth, and lack of Science, especially Islam. The problem of poverty is a condition that islam doesn't want. In Islamic teachings, it is instructed to pay attention to the obligation of Muslims who are able to spend some of their wealth in the form of zakat, infaq, and sodakoh, which is specifically intended for the opor.

However, the boundaries of poor working community have ther criteria of not being able to get daily needs, do not have a permanent job, do not have adequate housing. likewise, the limited capital that they have cause they cannot return the final worth. Based on BPS, Recap 00-a, the number of low households according to the poor classification printed on 09/20/2016 16:58:40, stated that the number of poor working communities of Panjang district is 4,429 poor households. Meanwhile, Sukaraja Village is a categorized that total of poverty is 292 poor households. ${ }^{8}$

Based on the data taken from Panjang district office, the population of Panjang Sub-District is 40,099 from 4070 families and 38,099 of them are moslem. from the total of population, there are 11.099 having different background of education, 341 are as graduates from higher education both from Lampung and from Outside Lampung, but the number of elementary school graduates is more dominated if its compred with others.

The taklim Council in Panjang District where the location of research was taken consists of 8 Taklim assembly, namely: Way Lunik Village (Taklim Council of Al Hidayah , Ketapang Village (Taklim council of Al Munziri ), Ketapang Kuala Village (Taklim council of Al Yusron ), Pidada Village (Taklim Council of Al Aqso ), North Panjang Village (Taklim Council of Al Masripah ), Southern Panjang Village (Taklim Council of Al Iklas ), Karang Maratim village (Taklim council of Nurul Iklas), Serensam Village (Taklim council of Nurul Iman). while Islamic Boarding Schools or it is called as Pondok Pesantren in Panjang distric is located in Serangsem Village (Pondok Pesantren Asslafiyyah), Karang Maratim Village (Pondok Pesantren Ruadhatul Jannah), southern Panjang Village (Pondok Pesantren Nurul Iklas). ${ }^{9}$

Community in Panjang district consist of various socio-religious and complex cultural backgrounds can sometimes find it difficult to accept da'wah messages. One of the reasons is because The preachers often perceive that the object of Dakwah as vacuum society, for examples when they come home from their work will avoid to attend the ta'lim council becuse they are too tired and the material is not interested. Whereas, the preachers are now dealing with a community setting that has more variaty of styles with different conditions and problems. seeing the such condition, it is ofcourse neeeded to have more prachers with high quality and have more sincerity in conveying the messages using their own methods and strategies in their da'wah to achieve the maximum success of islamic preaching.

\footnotetext{
${ }^{6}$ Toto Tasmara, Komunikasi Dakwah (Jakarta: Gaya Media Pratama, 2015), xiii.

7 Tasmara, xvii.

8 Badan Pusat Statistik, "Rekap 00-a Propinsi Lampung, Jumlah Rumah Tangga Menurut Klasifikasi Miskin," 19 Juli 2016.

9 Sopyan, Interview Staf KUA Panjang, 21 Januari 2019.
} 
Islam views the empowerment of civil society as an important thing so that empowerment in an Islamic perspective will have holistic and strategic approaches. In this regard, Islam has strategic and holistic paradigm in viewing it. According to Mattoriq, empowerment in the context of developing an Islamic community is a lesson for the community so that they can independently make efforts to improve the quality of their lives, both concerning their welfare and safety in the world as well as their welfare and safety hereafter. ${ }^{10}$

Intellectual (religious knowledge) and regulation of worship (religious practice) are part of diversity. To reveal this phenomenon scientifically, the following points out one of the concepts adopted by many psychologists and sociologists, namely the concept of religiosity formulated by C. Y. Glock \& R. Stark. Both take elements of religious beliefs (aqidah) as ideological and conceptual dimensions. Religious practice is as a ritual dimension, religious feeling is as the dimension of experience, and Religious knowledge is as an intellectual dimension. Religious effects are as the consequence dimension (effects) displayed in more actions that reflect one's selfimage. ${ }^{11}$

The people of the Panjang District are dominated by Lampung and Javanese tribes. Meanwhile, in the terms of livelihood, the poor community labor community in Sukaraja Village are as factory workers, farmers, traders, and entrepreneurs.12 On the other hand, The preacher in delivering Dakwah messages is required to use various strategies so that the message conveyed will be easily received by the community. Ta'lim council community do not only perform reciting but also perform activities like of kosidahan, tamboura, and savings and loan to encourage and keep the spirit exsists.

The issue of empowerment in principle is concerned with the fate of the lives of all levels of society; hence ideally, the policy that has been set needs to be known by the public so that there is no misunderstanding (miss-communication) between the governing ruled parties. Community participation in development cannot be ruled out because in the midst of heterogeneous layer of society, there are social systems that skew to have a playful attitude and always control the process of the course of a wheel of government. Audiences are essentially not passive at all, but active, so that between communicators and communion not only occur interconnected but can also be influenced by connection or audiences. It needs to be understood that the essence of empowerment is a process. So during that process, there will be interactions involving some elements of the social system that can affect how the empowerment process goes. None of this escapes the role of communication. It's the same as the essence of empowerment. ${ }^{13}$ Communication is the process of sending a message by a person to others to inform, change attitudes, opinions, or behaviors either directly orally or indirectly through the media. ${ }^{14}$

The role of the preacher in such conditions is needed to change the condition better, fostering a society that does not understand the values of religion into understanding and being accepted and applied in daily life to become a complete Muslim. The role of the preacher as a lecturer in the teaching of Islamic goodness has an essential role for the community as a guide in understanding religious values, especially in the working community.

The preacher meant in this research is those who have institution under the umbrella, which is called as majelis Ta'lim or Ta'lim council. The primary resource where the data were taken consists of Religious leaders, public figures, government, and Islamic boarding schools. And the uniqueness of Panjang District as a research location is its high preaching atmosphere, this is

10 Matthoriq Matthoriq, "Aktualisasi Nilai Islam dalam Pemberdayaan Masyarakat Pesisir (Studi pada Masyarakat Bajulmati, Gajahrejo, Kecamatan Gedangan Kabupaten Malang)," Jurnal Administrasi $\begin{array}{lllllll}\text { Publik 2, } & \text { no. } & 3 & & \text { Mei } & 2014): & 426-432-432 \text {, }\end{array}$ http:/ /administrasipublik.studentjournal.ub.ac.id/index.php/jap/article/view/405.

11 Rodney Stark dan Charles Y. Glock, Religion and Society in Tension (Chicago: Rand McNally \& Company, 2005), 18-38.

12 Koirun Has, Interview Da'i Panjang, 15 Februari 2019.

13 Anwar Arifin, Strategi Komunikasi (Bandung: CV. Armico, 1989), 59.

14 Onong Uchjana Effendi, Dinamika Komunikasi (Bandung: PT. Remaja Rosdakarya, 1993), 5. 
proven by the Office of Religious Affairs of Panjang District as the mational model nominee of religious affairs (KUA) in 2019. Labor as a sample can be said that it is also unique because the workers work entirely in the factory, but if it is seen from religious observance, they are very aware of the insanity for hereafter. In terms of empowerment with the existence of Majelis ta'lim, one of the programs of the mad' $u$ is to carry out arisan either in the form of money or materials for the construction of residences. The results of the survey shows that the current increase in religious practice is not so good, this is based on the fact that workers do less to perform dawn prayers, maghrib, isya congregations in mosques, or Mushola.

Suppose we look at the construct of character education for the young generation of Lampung, which is presented in local cultural values and has been used as a philosophy of life, namely Piil Pesenggiri. Within the cultural values of indigenous peoples, there are four constructs of character education values that are beneficial to someone. Namely Meet Nyimah, Nengah Nyappur, Sakai Sambaiyan, and Juluk Adok. The four constructs of character education can be applied in everyday life to grow one's self-esteem. ${ }^{15}$ The shift in the paradigm of Islamic education that occurred in the indigenous people of Lampung was caused by several factors, namely internal factors, and external factors. About internal factors, namely the dominance of the mindset of parents and human resources. Meanwhile, external factors, namely globalization, modernization, cultural dynamics, and social change, have become challenges for Islamic education. Even Islamic boarding schools or Islamic educational institutions are considered to have no relevance to the times' progress. ${ }^{16}$

Besides, the preacher tested the community on certain days to see their situation and condition. in conducting the survey, it was found some problems from the number of 8 councils that the labor community has already been exists, but the level of desire to learn and study religion especially Islamic prequel is still not good and not maximum yet, include their presence to the ta'lim council. Based on the above background, the author is interested in conducting in depth research by appointing the title "Dawah Communication Strategy on Empowering The Working People in Bandar Lampung City Panjang District in Improving Religious Practice."

The type of research used in this study is field research that examines the facts and problems occured in the field. Meanwhile, the nature of this research includes descriptive research that describe the condition of the field in Panjang District of Bandar Lampung City.

The purpose of this research is to describe the role of da'wah communication strategy. To find out why something occured, a contextually comprehensive view of the goal is needed. Therefore, the approach that is considered appropriate is qualitative. Qualitative research is considered suitable because it is natural and requires wholeness according to the problem of this study. In this study, the authors divided the resource into two parts:

1. Primary Data Source

Primary data is data obtained directly from its source, observed, and recorded for the first time. ${ }^{17}$ The primary data in this study was the opinions of subjects (people) individually or in groups, and test results. The subject's opinion stipulated individually or in this study is the executor with the total number preachers about 20 people, man's (labor) about 16 employees. Researcher, with primary data collected as desired in the study, because data that is not relevant to the purpose of the study can be eliminated or at least reduced

2. Secondary Data Source

15 Syaripudin Basyar, Zulhannan Zulhannan, dan Ahmad Muzakki, "Islamic Characters Education Construct Of Young Generation Based On Local Cultural Values Of Lampung Indigenous Peoples," AKADEMIKA: Jurnal Pemikiran Islam 25, no. 1 (2020): 65-90, https://doi.org/10.32332/akademika.v25i1.1739.

${ }^{16}$ Ahmad Muzakki, Dedi Wahyudi, dan Zuhairi Zuhairi, "Shifting Islamic Education Paradigm On Lampung Tradition Community," AKADEMIKA: Jurnal Pemikiran Islam 24, no. 1 (18 September 2019): 117, https://doi.org/10.32332/akademika.v24i1.1616.

17 Husain Umar, Strategi Managemen In Action (Jakarta: Gramedia Pustaka Utama, 2015), 42. 
Secondary data is data that is not attempted by the collector himself. ${ }^{18}$ Related to this study, the authors looked for other materials related to the subject matter, namely the strategy of Dakwah. Secondary data sources are government officials, religious figures, public figures, books, magazines, newsletters, and so on. According to Ustad Firliansyah, Lc addressed in Way Halim Village, Way Halim District, Bandar Lampung that the strategy of Dawah Communication in empowering the labor community in improving religious practice that communicators (The preacher) are the people who convey the message to man's (communion) by oral means. While the sources that the communicator references are the Qur'an and Hadith. Sumber is the basics used to strengthen the message itself. Sources can be people, institutions, books, and documents, or the like. The sources of Dakwah are the Qur'an and al-Hadith.

In qualitative research, there is a slogan the researcher is the key instrument. Therefore, the position of the researcher is like a planner, executor of the data collector, data analyst, data interpreter and in the end, he becomes the reporter of the results of his research. Thus only researchers can be used as instruments in this study. To facilitate its task, assisted by observation guidelines, interviews, and documentation so that the necessary data can be fulfilled.

The method of data analysis in this study is descriptive, i.e. the technique of deciphering, describing, and interpreting the data obtained. Besides, it is also used content analysis method, namely the process of analysis of the meaning and content of texts and statements related to the form of dawah communication against poor workers in Bandar Lampung Panjang District. The analysis method is as follows:

\section{B. Village Profile And Data Analysis Presentation}

\section{Village Profile}

Geographic / District Area and Topography

Based on Bandar Lampung Regional Regulation No. 04/2012, on The Arrangement and Establishment of Villages and Sub-Districts, the geographical and administrative location of Panjang District comes from some geographical and administrative areas of Panjang SubDistrict and Teluk Betung Selatan sub-districts with the following boundaries:

a) The north is bordered by Sukabumi Sub-District

b) The south is bordered by TelukLampung

c) The east is bordered by Lampung Regency South

d) The west is bordered by BumiWaras Sub-District ${ }^{19}$

Panjang district is topographically part of lowland/coastal area and other part is part of the hilly area. ${ }^{20}$

2. Government Administration

The Government of Panjang District was formed since 1976, located in Lampung Province based on Law No. 14 of 1994. In 2012, based on Bandar Lampung City Regional Regulation Number 04 of 2012, on The Arrangement and Establishment of Villages and SubDistricts, the Panjang Sub-District area is divided into 8 (eight) subdistricts, namely:

a. Karang Maritim Village,

b. South Panjang Village,

c. North Panjang Village,

d. Pidada Village,

e. WayLunik Village,

\footnotetext{
18 Umar, 42.

19 “Document Profile Kecamatan Panjang," 2019.

20 "Document Profile Kecamatan Panjang."
} 
f. Ketapang Village,

g. Ketapang Office of religious kuala Village,

h. Ketapang Village

The government centre of the Panjang District is located in Karang Maritim Village. Then to realize the implementation of the government, the Decree of the Mayor of Bandar Lampung Number: 31 the Year 2008, dated February 11, 2008, on the Organizational Structure of The Government of Bandar Lampung Panjang District. ${ }^{21}$

3. Data Presentation and Analysis

a. Data Presentation

1) Dawah Communication Strategy in Empowering The Labor Community in Panjang District is to change behaviour in the labor community, the preacher in the sub-district do not only communicate Dakwah verbally but also in bilingual as well. The media used in preaching is by oral and using loudspeakers, and the material conveyed is Islamic material consists of motivations of their daily life. 22

2) Community Empowerment

The empowerment in this study are as follows:

a) Empowerment in Matra Ruhaniah

Held studies (liqo' / council in religious development) in, Panjang district, Bandar Lampung city, and sponsoring the orphans.

b) Intellectual Empowerment

Special studies are held for the elderly every sunday and regular ta'lim every week.

c) Economic Empowerment

The council held arisan during a routine lecture, party, and building meter material to empower the working people, as well as one of the religious leaders in the village facilitating vehicles (two trucks and one private car) for villagers, to make it easier for Panjang residents to attend religious events.

A strategy is an entire set of steps and sets of wisdom to achieve a goal or to address existing problems. ${ }^{23}$ While other understandings, according to Sondang P. Siagian strategy can be defined by the basic policies directly related in achieving goals that include funding and human resources taking into account the internal and external conditions of the organization. ${ }^{24}$

Dakwah communication is a process of delivering messages in the form of Islamic teachings (Islamic messages) persuasively (bil hikmah) in the hope that communication can behave and practice pious by the teachings of Islam, ${ }^{25}$ which is referred to in this discussion is the process of communication dawah in the form (forum) study of council where The preacher acting as a communicator with the community (man's) acts as a communion. Furthermore, the labor community in question is the labor community in Panjang District in council study is held every Friday and Tuesday at 14.00 WIB-16.00 WIB while the material revolves around daily life with the aim of better their lives than ever before.

In the English dictionary mentioned, the strategy is the art of using the resources of nations to carry out specific policies in warfare, or care plans on activities to achieve particular goals. ${ }^{26}$

Dakwah strategy means methods, tactics, or maneuvers used in the activities (activities) of Dakwah. In other words, the Dakwah strategy is planning that contains a framework of activities

21 "Document Profile Kecamatan Panjang."

22 Yusuf dan Iwan, Interview Da'i Kecamatan Panjang, 2 Maret 2019.

${ }^{23}$ Mijoyo dan Jaya, Teori Dan Strategi Pembangunan Nasional, 13.

${ }^{24}$ Sondang P. Siagian, Analisis Serta Penemuan Kebijakan dan Strategi Organisasi (Jakarta: Gunung Agung, 2013), 17.

${ }^{25}$ Tasmara, Komunikasi Dakwah, 38.

26 Pusat Bahasa Departemen Pendidikan Nasional RI, Kamus Besar Bahasa Indonesia (Jakarta: Balai Pustaka, 2005), 1092. 
designed to achieve specific Dakwah objectives. Dakwah strategy is the process of determining about how to deal with the purposes of Dakwah in certain situations and conditions to achieve the objectives of Dakwah optimally. In achieving this goal, the Dakwah strategy must be able to show how technically operational (tactical) should be carried out, in the sense that the approach can vary at any time depending on the situation and the condition.

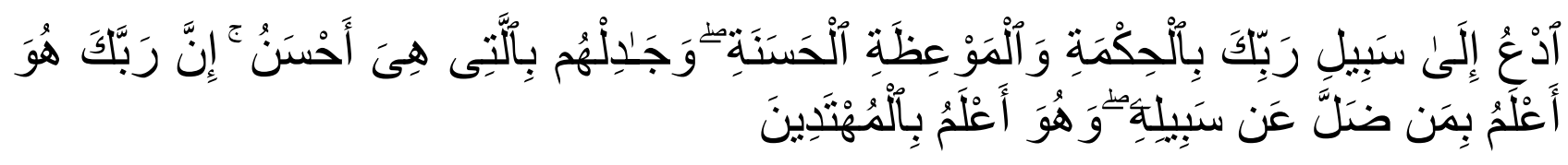

"Invite 'all" to the Way of your Lord with wisdom and kind advice, and only debate with them in the best manner. Surely your Lord 'alone" knows best who has strayed from His Way and who is "rightly' guided."

As mentioned in verse, three strategies are used to carry out Dakwah, namely: Wisdom (with wisdom), Mau'izhah Hasanah (good counsels), Mujis bil latii hiya ahsan (discussion in a good way). Also, there are three strategies of Dakwah, namely: the tilawah strategy (reciting the verses of Allah Almighty), the tazkiyah strategy (purifying the soul), and the council strategy (teaching the Qur'an and al-hikmah). And there are three forms of Dakwah strategy:

1) Sentimental strategy. It is the Dakwah that focuses on the aspect of the heart and moves the feelings and souls of the Dakwah partners. This strategy, the soft feel valued, and the noble feel respected.

2) Rational strategy. It is Dakwah with several methods that focus on the aspects of mind.

\section{Empowerment of the Labor Community}

Empowerment comes from the word "power" which gets the prefix into the word "empowered" meaning to have or have power. Power means energy that has sense of strength. The term "empowered" when given the prefix pe- by getting inserts -- and endings -- so "empowerment" means to make something empowered or have power. ${ }^{27}$

The word "empowerment" is derived from the bare word "power" which means the power of doing, achieving, or enabling. The prefix "em" empowerment can mean strength in man, a source of creativity. ${ }^{28}$ Therefore, the main idea of charge comes into contact with the concept of power. Power is often associated with our ability to make others do what we want, regardless of their desires and interests. Traditional social sciences emphasize that power is something that does not change or cannot be changed. Therefore, power and power relations can change in other words, the possibility of the empowerment process depends on two things:

a. Power may change. If energy cannot change, strength cannot happen in any way.

b. Power can be expanded. This concept emphasizes the notion of energy that is not static but rather dynamic. ${ }^{29}$

\section{Worship / Religious Experience}

\section{a. Experience}

Practice in this case can be meant as the charity, which has the meaning of a practised thing or act. ${ }^{30}$ It is about the process of conducting or implementating an activity, duty, or obligation. ${ }^{31}$

${ }^{27}$ Rosmedi dan Riza Risyanti, Pemberdayaan Masyarakat (Sumedang: Alqaprit Jatinegoro, 2006), 1.

28 Lili Baridi, Muhammad Zein, dan M. Hudri, Zakat dan Wirausaha (Jakarta: Center for Enterprenership Development, 2005), 53.

${ }^{29}$ Edi Suharto, Membangun Masyarakat Memberdayakan Rakyat (Bandung: Refika Aditama, 2010), 5758.

30 Pusat Bahasa Departemen Pendidikan Nasional RI, Kamus Besar Bahasa Indonesia, 33.

${ }^{31}$ Jamaluddin Ancok dan Fuat Nashori, Psikologi Islam (Yogyakarta: Pustaka Pelajar, 2017), 77. 
According to Glock and Stark, there are five kinds of religious strategies namely belief (ideology), the dimension of worship or spiritual practice (ritualistic), imaginary size (experimental), the size of religious knowledge (intellectual).

b. Islamic Religious Education Values

Islamic religious values are essentially intended as collection of principles of life, teachings on how human being should live in this world, where one principle interrelated to form unified whole that cannot be separated. Don't think that there is one stand-alone value. So Islam is one system, one package, a package of values that are intertwined with each other, forming what is called the standard Islamic theories. ${ }^{32}$ Islamic values can be seen in two aspects: normative values and operative values. In the Qur'an, there are normative values that are referenced in Islamic education. The value in question consists of three main pillars, namely:

1) I'tiqadiyyah, which deals with faith education, such as believing in God, angels, the messenger, books, the last day, and destiny, which aims to organize your beliefs individually.

2) Khuluqiyah, which deals with ethics education, which aims to rid oneself of low behavior and embellish with praiseworthy behavior.

3) Amaliyyah, which deals with the education of daily behaviour, is both related to 'the knowledge of worship and the teaching of practice or muamalah. ${ }^{33}$

While the operative values according to Zulkarnain in his measure of the transformation of Islamic Education values mentioned that Islamic religious values include four main aspects namely Tauhid, Worship, Moral and Societal values.

\section{E. Conclusion}

The teachings of Islam that have been conveyed by Ustadz or Ustadzah until now have always discussed a matter that is very closely related to the life of all mankind. Where all aspects of life, there will always be a subject that can be used as the material in preaching. either it is about aqidah, akhlakulkarimah, or sharia in Islam. The process of delivering the message carried out by the preacher in spreading their Da'wah is always centred on the Sciences of the Qur'an and Sunnah of the Prophet. Thus, when all members gather for deliberation discussing Dakwah programs everything will be then implemented in the future based on clarity on life guidelines aimed at all Muslims. Participatory Communication (Feedback) from the Community after following the study of the preacher) The preacher continues to focus through what channels the message can be witnessed to cover the whole community without any restrictions. This is what keeps the preacher focused on conveying Dakwah participatory because of the use of media that has been motivated by the needs and objectives defined by each individual itself. Re-delivery.

Examining the values of Islam thoroughly is a huge task because these islamic values involve various aspects and require a broad study. The points that should be considered in the teachings of Islam is to determine values in improving the practice of which involves three aspects; Tauhid Value, Sharia Value, and Moral Value.

Based on the descriptions in the previous chapters, the authors concluded the results of the study that the authors carried out on the Dawah Communication Strategy. The effective communication strategy is to use Interpersonal Communication with direct response da'wah messges the message of dawah response directly carried out from one house to another house, arguing that workers or labor are busy about working, low level of education stimulus or stimulation for allmankind, The preacher, and takilim assembly distribute mukena, sarong, and qur'an with an unspecified schedule either at the time of the dawn prayer (which is held every Sunday morning) or during the recitation of ta'lim assembly.

32 Fuad Amsyari, Islam Kaffah Tantangan Sosial dan Aplikasinya di Indonesia (Jakarta: Gema Insan Press, 1995), 22.

33 Abdul Mujib, Ilmu Pendidikan Islam (Jakarta: Kencana Prenada Media, 2016), 36. 
The teaching materials are in the form of tauhid, tafsir, figh, hadith, morals, Islamic dates, or life issues in terms of aspects of Islamic teachings. the diversity of mad' $u$ is due to factors such as ethnicity, economy, social, psychological, socio-cultural, geographic, and carefully analyzing actions that affect preaching activities. The principle of da'wah used is the principle of the ability and expertise of preachers where this principle concerns the discussion of the professionalism of the da'i which becomes the subject of da'wah; of course, We use a different approach to Community empowerment in the economic field, Spiritual and Intellectual Matra.

\section{REFERENCES}

Amsyari, Fuad. Islam Kaffah Tantangan Sosial dan Aplikasinya di Indonesia. Jakarta: Gema Insan Press, 1995.

Ancok, Jamaluddin, dan Fuat Nashori. Psikologi Islam. Yogyakarta: Pustaka Pelajar, 2017.

Arifin, Anwar. Strategi Komunikasi. Bandung: CV. Armico, 1989.

Badan Pusat Statistik. “Rekap 00-a Propinsi Lampung, Jumlah Rumah Tangga Menurut Klasifikasi Miskin," 19 Juli 2016.

Baridi, Lili, Muhammad Zein, dan M. Hudri. Zakat dan Wirausaha. Jakarta: Center for Enterprenership Development, 2005.

Basyar, Syaripudin, Zulhannan Zulhannan, dan Ahmad Muzakki. "Islamic Characters Education Construct Of Young Generation Based On Local Cultural Values Of Lampung Indigenous Peoples." AKADEMIKA: Jurnal Pemikiran Islam 25, no. 1 (2020): 65-90. https:// doi.org/10.32332/akademika.v25i1.1739.

“Document Profile Kecamatan Panjang," 2019.

Effendi, Onong Uchjana. Dinamika Komunikasi. Bandung: PT. Remaja Rosdakarya, 1993.

Has, Koirun. Interview Da'i Panjang, 15 Februari 2019.

Matthoriq, Matthoriq. "Aktualisasi Nilai Islam dalam Pemberdayaan Masyarakat Pesisir (Studi pada Masyarakat Bajulmati, Gajahrejo, Kecamatan Gedangan Kabupaten Malang)." Jurnal Administrasi Publik 2, no. 3 (20 Mei 2014): 426-432-432. http://administrasipublik.studentjournal.ub.ac.id/index.php/jap/article/view/ 405.

Mijoyo, Bintoro Tjokro, dan Mustafat Jaya. Teori Dan Strategi Pembangunan Nasional. Jakarta: Gunung Agung, 2015.

Mujib, Abdul. Ilmu Pendidikan Islam. Jakarta: Kencana Prenada Media, 2016.

Muzakki, Ahmad, Dedi Wahyudi, dan Zuhairi Zuhairi. "Shifting Islamic Education Paradigm On Lampung Tradition Community." AKADEMIKA: Jurnal Pemikiran Islam 24, no. 1 (18 September 2019): 117. https:/ / doi.org/10.32332/akademika.v24i1.1616.

Nasor, M. "Dakwah Sebagai Instrumen Penanggulangan Radikalisme Di Era Digital." AKADEMIKA: Jurnal Pemikiran Islam 22, no. 1 (2017): 27-50. https:// doi.org/10.32332/akademika.v22i1.613.

Ninsiana, Widhiya. "Islam Dan Integrasi Sosial Dalam Cerminan Masyarakat Nusantara." AKADEMIKA: Jurnal Pemikiran Islam 21, no. 2 (2016): 357. https://ejournal.metrouniv.ac.id/index.php/akademika/article/view/472.

Pusat Bahasa Departemen Pendidikan Nasional RI. Kamus Besar Bahasa Indonesia. Jakarta: Balai Pustaka, 2005.

Rosmedi, dan Riza Risyanti. Pemberdayaan Masyarakat. Sumedang: Alqaprit Jatinegoro, 2006.

Siagian, Sondang P. Analisis Serta Penemuan Kebijakan dan Strategi Organisasi. Jakarta: Gunung Agung, 2013.

Sopyan. Interview Staf KUA Panjang, 21 Januari 2019.

Stark, Rodney, dan Charles Y. Glock. Religion and Society in Tension. Chicago: Rand McNally \& Company, 2005.

Suharto, Edi. Membangun Masyarakat Memberdayakan Rakyat. Bandung: Refika Aditama, 2010.

Suyadi, Suyadi. "Mainstreaming The Knowledge Of Islamic Education With Progress And Of 
Islam Nusantara Education." AKADEMIKA: Jurnal Pemikiran Islam 24, no. 1 (2019): 39-66. https:// doi.org/10.32332/akademika.v24i1.1613.

Tasmara, Toto. Komunikasi Dakwah. Jakarta: Gaya Media Pratama, 2015.

Umar, Husain. Strategi Managemen In Action. Jakarta: Gramedia Pustaka Utama, 2015.

Yusuf, dan Iwan. Interview Da'i Kecamatan Panjang, 2 Maret 2019.

Zamhari, Arif, dan Imam Mustofa. "The Popular Da'wah Movement In Urban Communities: The Role Of Hadrami Scholars' Da'wah In Response To Religious Radicalism In Indonesia." AKADEMIKA: Jurnal Pemikiran Islam 25, no. 1 (2020): 185-208. https:// doi.org/10.32332/akademika.v25i1.2385. 